\title{
Tomato yellow leaf curl virus Can Be Acquired and Transmitted by Bemisia tabaci (Gennadius) from Tomato Fruit
}

\author{
H. Delatte, CIRAD 3P, Ligne Paradis, 97410 Saint Pierre, Réunion, France; A. Dalmon, Laboratoire National de la \\ Protection des Végétaux, Domaine St. Maurice, B.P. 94, 84143 Montfavet cedex, France; D. Rist, Protection des \\ végétaux, CIRAD-3P, Ligne Paradis, 97410 Saint Pierre, France; I. Soustrade, CIRAD 3P, Ligne Paradis, 97410 \\ Saint Pierre, Réunion, France; G. Wuster, Protection des végétaux, CIRAD-3P, Ligne Paradis, 97410 Saint Pierre, \\ France; J. M. Lett, CIRAD 3P, Ligne Paradis, 97410 Saint Pierre, Réunion, France; R. W. Goldbach, Wageningen \\ University, Binnenhaven 11, 6709 PD Wageningen, The Netherlands; M. Peterschmitt, CIRAD, TA 40/02, 34398 \\ Montpellier cedex 5, France; and B. Reynaud, CIRAD 3P, Ligne Paradis, 97410 Saint Pierre, Réunion, France
}

\begin{abstract}
Delatte, H., Dalmon, A., Rist, D., Soustrade, I., Wuster, G., Lett, J. M., Goldbach, R. W., Peterschmitt, M., and Reynaud, B. 2003. Tomato yellow leaf curl virus can be acquired and transmitted by Bemisia tabaci (Gennadius) from tomato fruit. Plant Dis. 87:1297-1300.

The whitefly Bemisia tabaci is an insect pest causing worldwide economic losses, especially as a vector of geminiviruses such as Tomato yellow leaf curl virus (TYLCV). Currently, imported and exported tomato fruit are not monitored for TYLCV infection because they are not considered to represent a potential risk as a virus source for whiteflies. A survey of tomato fruit imported into Réunion Island indicated that more than 50\% of the fruit contained TYLCV as determined by DNA blot analysis. Moreover, we showed that TYLCV was present at a high titer in tomato fruit, and demonstrated that it can be acquired by whiteflies and subsequently transmitted to healthy tomato plants. Potential risk of the spread of TYLCV by tomato fruit in natural conditions needs to be further assessed.
\end{abstract}

Additional keywords: acquisition, transmission

In tropical and subtropical climate zones, Bemisia tabaci Gennadius (Hemiptera: Aleyrodidae) is an important insect pest. $B$. tabaci provokes direct feeding damages but also causes considerable indirect damage as a vector of numerous geminiviruses (3) such as Tomato yellow leaf curl virus (TYLCV; genus Begomovirus, family Geminiviridae), a threatening virus for tomato $(8,11,14)$. TYLCV initially was described from the eastern Mediterranean regions (2). In the last decade, due to international transport of plant material and people, TYLCV has spread to the western Mediterranean regions, the Caribbean Islands, the American continent, Réunion Island, and Japan $(1,6,12,13$, 16,17). Following the spread of TYLCV, the French National Plant Protection Organization (NPPO) is particularly concerned by the risk of any further spread of this virus and, more generally, by the spread of any other begomovirus. This risk is not limited only to

Corresponding author: M. Peterschmitt E-mail: michel.peterschmitt@cirad.fr

This work was funded by CIRAD, le Conseil Régional de la Réunion, and le Ministère de l'agriculture (SPV). This study is part of the Ph.D. thesis of H. Delatte from Wageningen University.

Accepted for publication 30 May 2003.

Publication no. D-2003-0829-03R

(C) 2003 The American Phytopathological Society tropical and subtropical regions because $B$. tabaci is also a major pest in greenhouses in temperate regions.

Presently, all control measures are focused on the vegetative plant parts and, particularly, on imported tomato seedlings produced in nurseries of begomovirusinfected countries, but were not applied to the imported fruit. A survey conducted in 2000 by the French NPPO has shown that $50 \%$ of tomato fruit introduced into France from Mediterranean countries were actually infected with TYLCV (A. Dalmon, unpublished results). In view of this, it has become necessary to repeat this survey and test if tomato fruit can act as a reservoir of viruses from which whiteflies would be able to acquire and spread the virus. In this study, we present the results of a survey conducted by the French NPPO in 2002 on the presence of TYLCV on tomato fruit imported into Réunion from TYLCV-infected countries. We showed that TYLCV was present in several parts of vine tomato fruit and that $B$. tabaci can survive for more than $12 \mathrm{~h}$ on fruit. Based on these results, we designed a transmission test which demonstrated that B. tabaci can acquire TYLCV from tomato fruit and transmit it to healthy tomato plants.

\section{MATERIALS AND METHODS}

Insect, plant, and virus material. Adults of B. tabaci used in this study were from a Réunion population that was started with nymphs collected on cabbage (Brassica oleracea) and subsequently reared on the same species under laboratory conditions: 12-h photoperiod (white and red fluorescent tubes), $25 \pm 2{ }^{\circ} \mathrm{C}$ temperature, and $60 \pm 10 \%$ relative humidity. The population was identified as belonging to the $\mathrm{B}$ biotype using random amplified polymorphic DNA markers. Fruit of cvs. Durinta (Western Seeds) and Cencara (Vilmorin) of vine tomato (Lycopersicon esculentum) were collected from TYLCV-infected plants in a greenhouse of Piton Saint Leu (Réunion). Transmission experiments were done on a TYLCV-susceptible cv. Farmer (Know You Seed).

Squash and tissue blot detection of begomoviruses on imported batches of tomato fruit. Twenty-seven batches of tomato fruit imported from different countries (principally Spain and Morocco) into Réunion Island during the first quarter of 2002 were assayed for begomovirus presence. In all, 12 to 50 randomly selected fruit were tested for each batch. Four small pieces (approximately 0.5 by 0.5 by 0.2 $\mathrm{cm}$ ), including skin and pulp, were sliced with a sterile scalpel near the point of insertion of the peduncle of each fruit and squashed individually onto a nylon membrane. Prints also were made on the membrane with cross sections of the stem for vine tomato plants. Prints of leaf and stem of healthy tomato plants were used as negative control on each membrane. Tomato fruit (skin and pulp) and leaves of TYLCV-infected plants were used as a positive control. Virus detection in squash blots and tissue prints were performed by hybridization with a TYLCV-DNA probe, using the DIG high prime DNA labeling and detection starter kit II (Roche, Mannheim, Germany), according to the manufacturer's recommendations. The TYLCV probe represented a 800-bp DNA fragment of a Réunion TYLCV isolate (GenBank accession no. AJ010790) including a 3' part of the precoat gene and a $5^{\prime}$ part of the coat protein gene. A sample was considered positive when a strong signal was revealed on the membrane compared with the negative control. 
TYLCV distribution in the vine tomato fruit. Two bunches of vine tomato of eight and nine fruit (cv. Durinta) and two others of five and four fruit (cv. Cencara) collected on TYLCV-infected plants were tested for TYLCV detection with tripleantibody sandwich enzyme-linked immunosorbent assay (TAS-ELISA) using a kit supplied by Adgen (Ayr, Scotland, UK). The protocol was according to the manufacturer's recommendations (Adgen). Virus distribution was assessed within each fruit by testing separately small pieces of stem, sepals, skin, pulp, and peduncle insert (point of insertion of the peduncle inside the fruit) sliced with a sterile scalpel. Plant samples of $0.5 \mathrm{~g}$ were ground in $3 \mathrm{ml}$ of extraction buffer. Positive and negative control were from tomato leaves collected on TYLCV artificially infected and noninfected plants, respectively, of susceptible tomato cv. Farmer. The detection of the virus was considered to be positive when the absorbance value was higher than the mean absorbance of the healthy control plus three times the standard deviation.

Survival test. Life expectancy of whiteflies feeding on bunches of tomato fruit (cv. Durinta) was assessed with $100 \mathrm{Be}$ misia tabaci individuals, which were introduced in two 1-liter beakers (50 whiteflies in each) covered with gauze mesh and containing one small bunch of tomato fruit in each. Dead insects were recorded after different time periods: $3,6,12,24$, and 48 h. The beakers were kept at $25^{\circ} \mathrm{C}$ with a 12-h photoperiod. The experiment was repeated once.

Transmission test. Bunches of vine Durinta tomato fruit used as virus sources for the transmission tests were cut from TYLCV-infected plants, and one fruit of each bunch was checked for TYLCV infection by TAS-ELISA. Three ELISApositive bunches, with about 6 to 8 tomato fruit each, were placed in a cage in which approximately 1,000 nonviruliferous $B$. tabaci whiteflies were released. Simultaneously, in another cage, about 1,000 insects from the same nonviruliferous population were placed on a TYLCV-infected tomato plant which did not bear fruit. After a 3-h acquisition access period (AAP), 100 insects were removed from each cage. Of these, 50 were caged on two-leaf-stage tomato plants with a plastic tube, one whitefly per plant, for a 7-day inoculation access period (IAP). To confirm virus uptake, the 50 remaining $B$. tabaci whiteflies were crushed individually on a membrane and analyzed with a TYLCV genome DNA probe (16). After removing the tubes at the end of the IAP, the plants were treated with an insecticide and placed in an insect-proof cage for 21 days in a greenhouse. The inoculated plants were analyzed for TYLCV detection with TAS-ELISA. The detection of the virus was considered to be positive

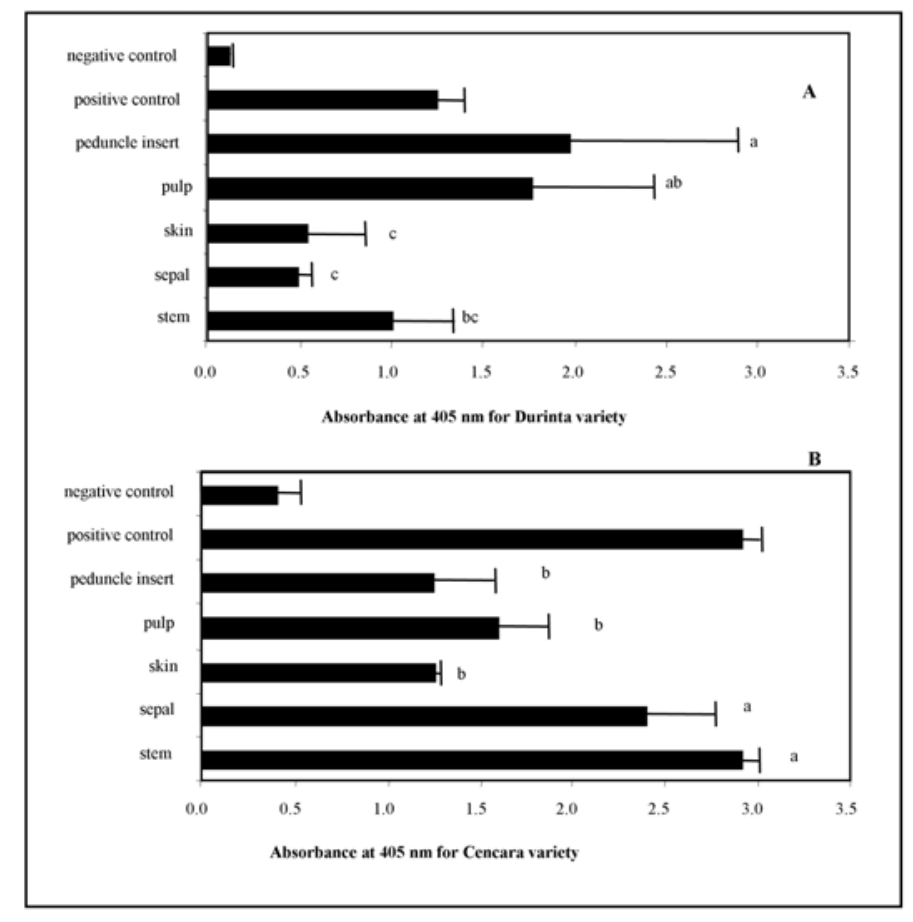

Fig. 1. Tomato yellow leaf curl virus (TYLCV) detection by triple-antibody sandwich enzyme-linked immunosorbent assay in different parts of $\mathbf{A}, 17$ vine tomato fruit of two infected bunches of cv. Durinta and $\mathbf{B}, 9$ fruit of two infected bunches of cv. Cencara. Positive and negative controls were from tomato leaves collected on TYLCV-infected and noninfected plants, respectively, of susceptible tomato cv. Farmer. The standard deviation is indicated for each mean absorbance. Fruit parts with the same letter indicate that their mean absorbance values were not significantly different according to the Tukey test $(\alpha=0.05)$. The controls were not included in the analysis of variance analyses and in the mean comparison test. when the absorbance value was higher than the mean absorbance of the healthy control plus three times the standard deviation. The same test was repeated after a 6- and a 12-h AAP. Three repetitions of the whole experiment were performed with tomato fruit from the same location and the same plants.

Statistical analyses. Analyses of variance (ANOVAs) were performed on transformed data ( 2 arcsinus $\sqrt{ } x / 100)$ for homoscedasticity on the mean absorbance values in ELISA tests for cvs. Cencara and Durinta on the different parts of the fruit: sepal, stem, pulp, skin, and peduncle insert (Fig. 1A and B). The same transformation and ANOVA test were performed on the percentage of ELISA-positive plants and on the percentage of viruliferous whiteflies for the transmission test. We used S-plus 6.1 (Insightful Corporation Seattle, WA), which proposes the best test of mean comparison in terms of critical point at level $\alpha$ $=0.05$.

\section{RESULTS}

Begomovirus detection on imported batches of tomato fruit. TYLCV-infected tomato fruit were found in 13 of 27 batches of imported tomato fruit coming from different origins (Table 1). On average, 57\% of the fruit from these 13 batches were infected with TYLCV.

TYLCV distribution in vine tomato fruit. All the fruit of the bunches of tomato fruit, green or mature, collected on TYLCV-infected plants of the cvs. Durinta and Cencara were shown to be infected by TYLCV using TAS-ELISA. All the fruit components tested for virus detection were positive by ELISA (Fig. 1A and B), although the relative distribution was significantly different for the two cultivars (Fisher and Tukey tests). The mean absorbance value obtained with peduncle insert was significantly higher than those obtained with skin, sepal, and stem for cv. Durinta (Fig. 1A). Inversely, for cv. Cen-

Table 1. Detection of Tomato yellow leaf curl virus (TYLCV) in 27 batches of tomato fruit imported into Réunion during the first quarter of $2002^{\mathrm{a}}$

\begin{tabular}{llc}
$\begin{array}{l}\text { Batch } \\
\text { number }\end{array}$ & Origin & $\begin{array}{c}\text { Positive fruit/ } \\
\text { total fruit tested }\end{array}$ \\
\hline 116 & Spain & $14 / 24$ \\
124 & Spain & $18 / 25$ \\
146 & Spain & $21 / 28$ \\
301 & Spain & $25 / 30$ \\
472 & Spain & $7 / 14$ \\
486 & Spain & $5 / 12$ \\
820 & Spain & $7 / 25$ \\
822 & Spain & $39 / 48$ \\
111 & Unknown & $10 / 24$ \\
158 & Unknown & $31 / 50$ \\
421 & Unknown & $18 / 50$ \\
390 & Morocco & $9 / 29$ \\
443 & Morocco & $11 / 18$ \\
\hline
\end{tabular}

a TYLCV was not detected in 14 batches of fruit from several countries (data not shown). 
cara, the mean absorbance values obtained with peduncle insert, pulp, and skin were significantly lower than those obtained with sepal and stem (Fig. 1B).

Survival test. Having confirmed that TYLCV was detected consistently in tomato fruit, a second prerequisite for virus transmission from tomato fruit was to show that whiteflies can feed and survive on bunches of tomato fruit. We recorded $20 \%$ mortality after a 24 -h feeding access on vine tomato fruit and almost $100 \%$ after 48 h (Fig. 2).

Transmission test. Based on the survival test results, transmission tests were carried out with three AAPs of 3, 6, and 12 h (Fig. 3). Of the insects used, 3\% were shown to transmit the virus to healthy tomato plants after a 3-h AAP on TYLCVinfected tomato fruit, and up to $8 \%$ after a 12-h AAP (Fig. 3A). The percentage of transmitters after AAP on whole plants was significantly higher (Fisher test and Fisher's least significant difference), with $8 \%$ after a 3 -h AAP, and up to $29 \%$ after a 12-h AAP. The percentage of transmitters increased significantly (Tukey test) with the increasing duration of the AAP from 3 to $12 \mathrm{~h}$ (Fig. 3A).

The percentage of insects that tested positive by TYLCV hybridization was generally higher than the percentage of transmitters (Fig. 3A and B). The percentage of viruliferous individuals increased significantly (Fisher test) with the increasing duration of the AAPs from 3 to $12 \mathrm{~h}$. However, no significant difference was found between the two sources of acquisition, fruit or whole plants (Fisher test and simulation-based test).

\section{DISCUSSION}

The results presented here are, to our knowledge, the first report of successful TYLCV transmission from fruit of vine tomato to tomato plants using B. tabaci as vector. This successful transmission was consistent with the ELISA detection of TYLCV in different parts of vine tomato fruit and the 24-h survival rate of $80 \%$ of a population maintained on such fruit. Although the feeding of the whiteflies does not appear very efficient on fruit regarding to the mortality rate, it seems sustained at least beyond the first $3 \mathrm{~h}$. Indeed, the percentages of viruliferous and infective whiteflies from the 12-h AAP were significantly higher than those from the 3-h AAP. A significant increase in the percentage of infective B. tabaci also was obtained with increasing AAPs on whole plants, as shown previously (9).

According to the absorbance values recorded by ELISA, TYLCV concentrations in tomato fruit may be relatively high when compared with the absorbance obtained with an infected tomato leaf (positive control). A 3-h feeding access on TYLCVinfected fruit was enough to obtain potentially infective whiteflies; therefore, the risk of TYLCV spread through this route cannot be disregarded wherever potentially infected tomato fruit are exported or imported to or from foreign countries. Be- cause other begomoviruses are threatening tomato production in various regions of the world, it will be useful to check how far this risk can be expected with these bego-

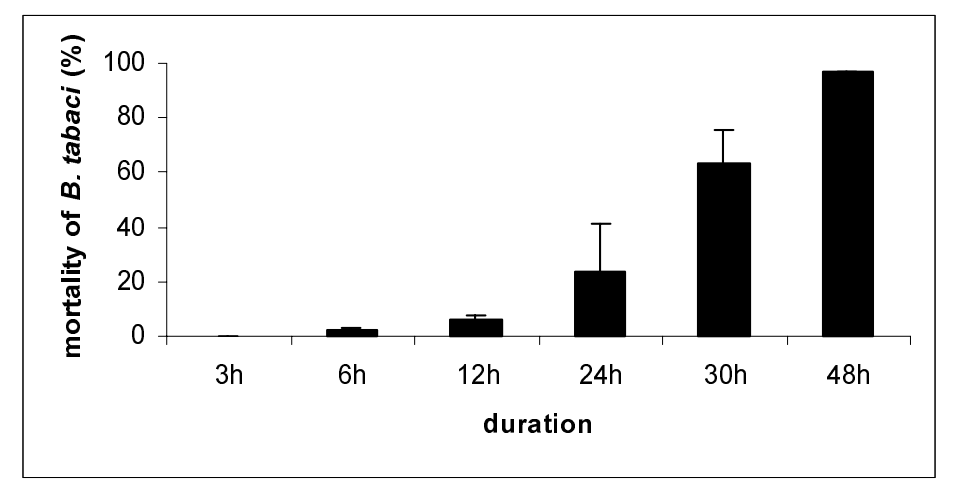

Fig. 2. Mortality recorded over time in a population of 200 Bemisia tabaci whiteflies separated into four groups of 50 individuals, each group maintained on a single bunch of tomato fruit (with approximately three to four fruit per bunch) within a 1-liter beaker. The vertical lines represent the standard deviation of the mean mortality of the four groups. The experiment was done twice.

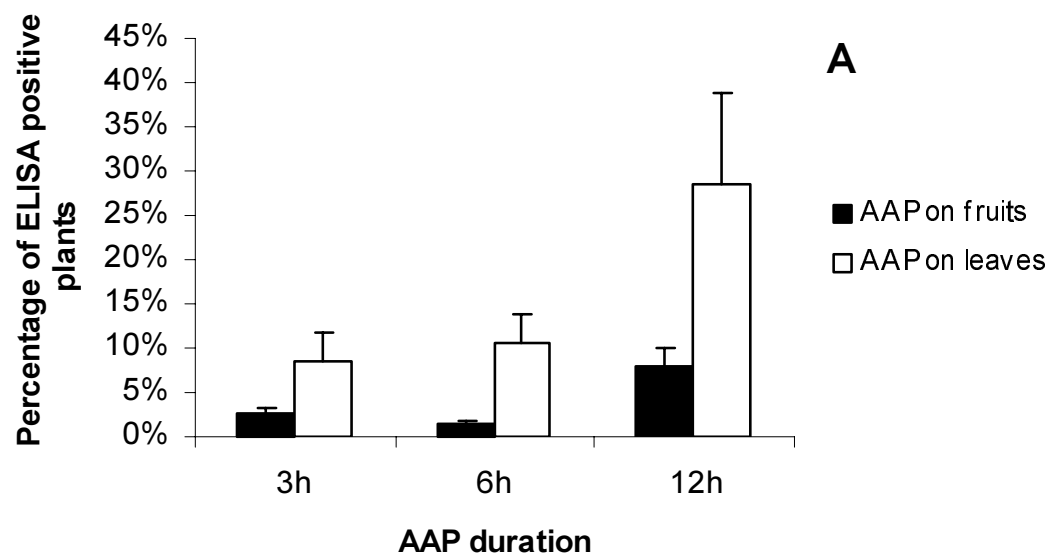

B

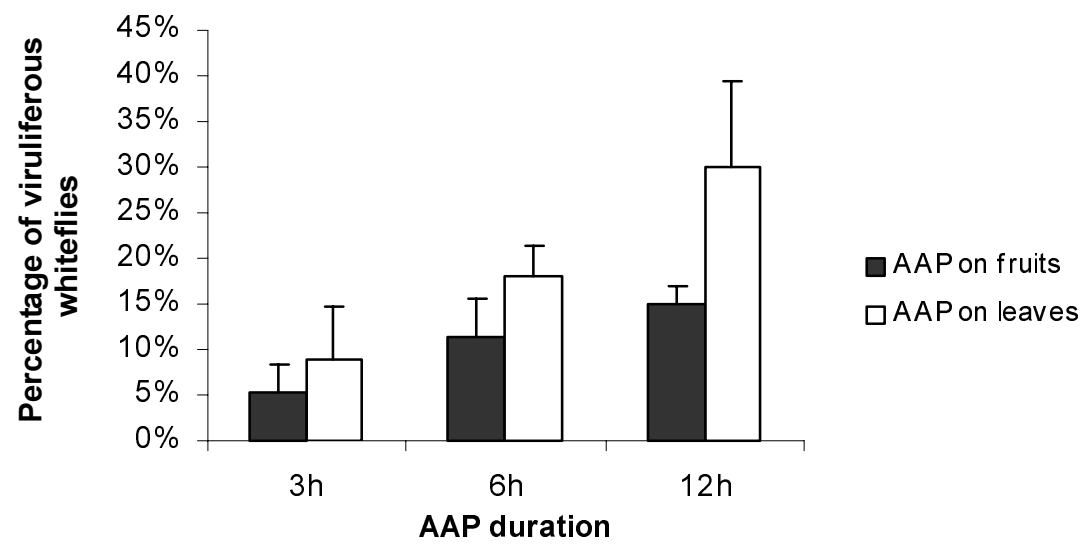

Fig. 3. A, Transmission of Tomato yellow leaf curl virus (TYLCV) from infected tomato fruit and seedlings to healthy tomato plants. These plants were tested by triple-antibody sandwich enzymelinked immunosorbent assay (ELISA) 3 weeks after the end of a 7-day inoculation access period with Bemisia tabaci individuals (1 whitefly per plant) which were given a 3-, 6-, or 12-h acquisition access period (AAP) on TYLCV-infected bunches of tomato fruit or whole plants of the vine tomato cv. Durinta. Fifty insects were used per AAP for each virus source. The experiment was repeated three times. The standard deviation is indicated for each mean percentage of ELISA-positive plants. B, Percentage of viruliferous whiteflies after the 3-, 6-, or 12-h AAP as determined by analyzing squashed individuals with a TYLCV genome DNA probe. Fifty insects were used per AAP for each virus source. The experiment was repeated three times. The standard deviation is indicated for each mean percentage of viruliferous whiteflies. 
moviruses. The risk of virus transmission from fruit previously was emphasized by others in the case of stone fruit, peach, and apricot with Plum pox virus (PPV) (7). However, unlike the stone fruit, which show symptoms due to PPV infection, the risk with TYLCV is emphasized because infected tomato fruit are symptomless.

The 57\% TYLCV-infected tomato fruit found, on average, in samples collected from 13 batches of tomato imported into Réunion from TYLCV-infected countries was consistent with the high infection rate detected in 2000 on tomato imported into France (A. Dalmon, unpublished results). Unfortunately, the use of commercial resistant tomato cultivars may not eliminate the risk of importing infected fruit because these cultivars do not prevent virus multiplication (4). Screening of resistant cultivars apparently never included TYLCV detection in the fruit $(5,10,15)$. Further studies are required to monitor virus in the fruit of resistant cultivars and also to find stronger resistances which may prevent contamination of the fruit or, at least, the parts to which the vector can have access. Indeed, the comparison between cvs. Durinta and Cencara showed that virus distribution within the fruit can be significantly different between two tomato cultivars.

One method to further assess the risk of TYLCV transmission from fruit in natural conditions would be to monitor the frequency of TYLCV transmission to healthy tomato plants caged with nonviruliferous B. tabaci and infected vine tomato fruit. According to observations made during the survival test, it seems that the whiteflies have a preference for the green parts of the tomato bunch, green tomato fruit, or green parts of further ripened fruit (sepal or stem), with red fruit (parts) being less fre- quented. This needs to be further investigated and substantiated with quantified data because it may help regulation personnel to design strategies to control the potential risk of virus spread through fruit. For the time being, although these risks were not yet assessed, it should be recommended to avoid the dumping of unmarketable infected tomato fruit near tomato fields.

\section{ACKNOWLEDGMENTS}

We would like to thank M. Grondin for his assistance in the transmission experiment and F. Chiroleu for his assistance in statistical analyses.

\section{LITERATURE CITED}

1. Accotto, G. P., Navas-Castillo, J., Noris, E., Moriones, E., and Louro, D. 2000. Typing of tomato yellow leaf curl viruses in Europe. Eur. J. Plant Pathol. 106:179-186.

2. Cohen, S., and Harpaz, I. 1964. Periodic rather than continual, acquisition of a new tomato virus by its vector, the tobacco whitefly (Bemisia tabaci Gennadius). Entomol. Exp. Appl. 7:155-166.

3. Credi, R., Betti, L., and Canova, A. 1989. Association of a geminivirus with a severe disease of tomato in Sicily. Mediterr. Phytopathol. 28:223-226.

4. Fargette, D., Leslie, M., and Harrison, B. D., 1996. Serological studies on the accumulation and localisation of three tomato leaf curl geminiviruses in resistant and susceptible Lycopersicum species and tomato cultivars. Ann. Appl. Biol. 128:317-328.

5. Friedmann, M., Lapidot, M., and Pilowsky, M. 1998. A novel source of resistance to Tomato yellow leaf curl virus exhibiting a symptomless reaction to viral infection. J. Am. Soc. Hortic. Sci. 123:1004-1007.

6. Kato K., Onuki M., Fuji S., and Hanada K. 1998. The first occurrence of Tomato yellow leaf curl virus in tomato (Lycopersicon esculentum Mill.) in Japan. Ann. Phytopathol. Soc. Jpn. 64:552-559.

7. Labonne, G., and Quiot, J. B. 2001. Aphids can acquire plum pox virus from infected fruits. Acta Hortic. 550:79-83.
8. Markham, P. G., Bedford, I. D., Liu, S. Frolich, D. F., Rosell, R., and Brown, J. K. 1995. The transmission of geminiviruses by biotypes of Bemisia tabaci (Gennadius). Pages 69-75 in: Bemisia. D. G. a. R. T. Mayer, ed. Intercept, Andover, UK

9. Mehta, P., Wyman, J. A., Nakhla, M. K., and Maxwell, D. P. 1994. Transmission of tomato yellow leaf curl geminivirus by Bemisia tabaci (Homoptera : Aleyrodiade). J. Econ. Entomol. 87:1291-1297.

10. Michelson, I., Zamir, D., and Czosnek, H. 1994. Accumulation and translocation of Tomato yellow leaf curl virus (TYLCV) in a $L y$ copersicon esculentum breeding line containing the L. chilense TYLCV tolerance gene Ty1. Phytopathology 84:928-933.

11. Moriones, E., and Navas-Castillo, J. 2000. Tomato yellow leaf curl virus, an emerging virus complex causing epidemics worldwide. Virus Res. 71:123-134.

12. Peterschmitt, M., Granier, M., and Aboulama, S. 1999. First report of Tomato yellow leaf curl geminivirus in Morocco. Plant Dis. 83:1074.

13. Peterschmitt, M., Granier M., Mekdoud, R Dalmon A., Gambin, O., Vayssieres, J. F., and Reynaud, B. 1999. First report of Tomato yellow leaf curl virus in Réunion Island. Plant Dis. 83:303.

14. Pico, B., Diez, M.-J., and Nuez, F. 1996. Viral diseases causing the greatest economic losses to the tomato crop. II. The Tomato yellow leaf curl virus-a review. Sci. Hortic. 67:151-196.

15. Pico, B., Diez, M.-J., and Nuez, F. 1999. Improved diagnostic techniques for Tomato yellow leaf curl virus in tomato breeding programs. Plant Dis. 83:1006-1012.

16. Polston, J. E., McGovern, R. J., and Brown, L. G. 1999. Introduction of Tomato yellow leaf curl virus in Florida and implications for the spread of this and other Geminiviruses of tomato. Plant Dis. 83:984-988.

17. Salati, R., Nahkla, M. K., Rojas, M. R., Guzman, P., Jaquez, J., Maxwell, D. P., and Gilbertson, R. L. 2002. Tomato yellow leaf curl virus in the Dominican Republic: Characterization of an infectious clone, virus monitoring in whiteflies, and identification of reservoir hosts. Phytopathology 92:487496. 